\title{
Prison infrastructure, the right to health and a suitable environment for the inmates of the Women's Annex in Chorrillos Prison (Peru)
}

\author{
Vildoso-Cabrera E ${ }^{1}$, Navas $\mathrm{C}^{1}$, Vildoso-Picón L ${ }^{2}$, Larrea L ${ }^{3}$, Cabrera $\mathrm{Y}^{4}$ \\ ${ }^{1}$ Faculty of Law and Political Sciences. National University of Federico Villarreal. Lima. Peru. \\ ${ }^{2}$ Faculty of Architecture and Town Planning. National University of Federico Villarreal. Lima. Peru. \\ ${ }^{3}$ Professional Nursing School of the National University of Faustino Sánchez Carrión. Huacho. Peru. \\ ${ }^{4}$ Science Department of the Postgraduate School of the National University of Federico Villarreal. Lima. Peru.
}

\begin{abstract}
Objective: To determine how the prison infrastructure can guarantee health rights and an adequate environment for inmates at the Women's Annex of Chorrillos Prison (EPAMCh.

Material and method: The materials consisted of a guided interview conducted with 10 specialists on the subject and a guided survey completed by 30 inmates. The method consisted of an applied qualitative approach with a phenomenological design.

Results: The experts interviewed said that the current infrastructure of the Women's Annex of Chorrillos Prison is in a state of crisis and does not provide even minimal healthcare services. The surveys completed by the prisoners gave the unanimous response that conditions were precarious, but the majority said that they were willing to form part of a health education program and to commit to preventive medicine without forgetting curative methods.

Discussion: Preventive medicine must be promoted. To do this, prisoners' educational levels need to be improved and solid health education systems in prisons should be provided. Changes would need to be made in the guarantees of their rights to health and to adequate surroundings to bring about the necessary changes.
\end{abstract}

Keywords: right to health, social adjustment, preventive medicine, prisons.

Text received: 19/06/2018

Text accepted: 26/01/2019

\section{INTRODUCTION}

The prison infrastructure includes the facilities, equipment, spaces and the prison itself, used to house inmates. The United Nations standard minimum regulations, which regulate prison matters, establish (from regulation 9 to 14) the close relationship between healthcare of inmates and the prison medical administration. At the same time it establishes the obligations borne by the competent administrative authorities to comply with and guarantee the minimum technical standards in terms of surface area and height of cell per person. Ventilation and lighting are also important factors, along with access to hygiene services inside the cell or if these are unavailable, to a suitable external area with working toilets and showers. Bedclothes and furniture for keeping personal items and washing materials are another factor.

The stipulations regarding the use of dormitories state that prisoners should be carefully selected and constantly watched over to prevent abuse or punishment of weaker prisoners by stronger ones. Body searches and inspections are useful mechanisms for ensuring that the regulations are complied with. Situations that do otherwise lead to an atmosphere of stress and extreme tension. 
In this vein, Chaiña ${ }^{1}$ argues that detention in a prison should not involve any more difficulties than those relating to the loss of freedom. The author adds that the incarceration areas should have enough space for sports activities, and not just be used as leisure spaces, but rather as a mechanism for maintaining inmates' health.

For its part, the sentence issued in case no. 14292002-HC-TC, handed down by the Constitutional Court of $\mathrm{Peru}^{2}$, argues that incarceration should not stop family relations from being maintained, since this is a major element in re-education and re-socialisation. This interpretation means that the prison administration should facilitate the development of family visits, and remove unreasonable or disproportionate limitations or obstacles, such as the unjustified use of booths, inappropriate personal searches, unexplained transfers, etc.

On the other hand, the right to health involves recognising and protecting physical as well as mental health. This was recognised by the World Health Organisation (OMS) in 1946 and by other national and international legal bodies.

Sentence T-760/08 3 , issued by the Constitutional Court of Colombia, stipulates that the right to health is fundamental and as such belongs to a human being because of his/her very condition, or rather, as the holder of an inimitable identity characterised by their rationality, which permits them to freely exercise their rights and wishes.

This case law matches that in other international instruments, of which Peru forms a part. Said instruments are as follows: the Minimum Regulations for the Treatment of Prisoners (1955), the International Covenant on Civil and Political Rights (1966), the American Convention on Human Rights (1969), the International Covenant on Civil and Political Rights (1976), the Convention against Torture and other Cruel, Inhuman or Degrading Treatment or Punishment (1984), the Body of Principles for the Protection of All Persons under Any Form of Detention or Imprisonment (1988), the Basic Principles for Treatment of Prisoners (1990), the Minimum Regulations of the United Nations Organisation (UNO) for Prisoners (1995), the International Covenant on Economic, Social and Cultural Rights (1996) and the Optional Protocol to the Convention against Torture and other Cruel, Inhuman or Degrading Treatment or Punishment (2002).

Peru is also protected by national regulations such as the Criminal Code (1991), the Penal Enforcement Code (1991) and the Constitution, which in article 139, paragraphs 21 and 22, establishes the right of inmates and convicts to occupy adequate facilities, stating that the aim of the prison system is to re-educate and rehabilitate prisoners. Finally, the right to a healthy environment, according to the Inter-American Institute of Human Rights ${ }^{4}$, includes inmates' basic needs and amenities, which should always be in the hands of the State, although private institutions and the prisoners themselves can contribute towards this end. For example, the way their food is prepared can be improved, hygiene guidelines can be put into practice for the areas they live in, workshops can be organised and implemented or sporting activities can be established. Thus, although the physical implementation is expensive, this need not be a pretext for generating an inadequate environment for prisoners and violate their human rights and dignity.

The Minimum Regulations of the United Nations place emphasis on a number of points for female inmates. An example of this is that women should be guaranteed everything they need for their personal hygiene during menstruation, while an agreeable and safe environment that engenders trust even in the smallest details should also be encouraged. One way of doing this is to have other women distribute sanitary towels, tampons or menstrual cups.

\section{IS THERE AN ADEQUATE ENVIRONMENT IN THE WOMEN'S ANNEXE OF CHORRILLOS PRISON IN PERU?}

To find out, a guided interview was conducted with 10 specialists on the matter: Carla Huerta Morales (lawyer of the National Prison Institute (INPE)); Eugenio La Torre Rebaza (lawyer of the INPE); Octavio Marín Marín (Head of Maintenance of the EPAMCh); Carlos La Serna Lora (Chief Physician of the EPAMCh); Amador Huamán Ventocillo, Jorge López Villar, Víctor Siguas Medrano, Edgar Garay Callalli and Octavio Suárez Rafael (specialist lawyers in Prison Law); and Luisa Núñez (representative of the Ombudsman). A survey was also designed for 30 inmates randomly selected by the prison medical team. These instruments were used between 10 October and 7 November 2017.

The method used consisted of an applied qualitative approach, because practical consequences of the results that might be obtained were sought. The objective was to contribute towards improving the reality of life in prison, based on the characterisation and qualification of the study categories. A phenomenological design was chosen because the aim was to interpret the meanings of the surroundings and the behaviour of the subjects. 


\section{INTERVIEWS WITH EXPERTS AND INMATES}

\section{Interview with the experts}

a. In response to the question: does the prison infrastructure guarantee the rights to health and an adequate environment for the inmates of the EPAMCh, the majority answered by stating that the current infrastructure was in crisis, on the verge of collapsing, due to prison overcrowding and the conditions of the building. The prison used to be a convent and its infrastructure was adapted to that of a prison with no technical support.

b. In response to the question: do the inmates have access to a prison infrastructure that permits minimum medical services in the EPAMCh, the majority answered that regrettably they did not. However, it was pointed out that the solution should not be limited to providing a larger budget, but prison health management policies also needed to be implemented. There is still a curative culture in Peru. It is often expected that the dispensary should be full of drugs to cure physical and mental illnesses. In their first year the inmates complain about supposed pains in order to obtain antidepressants, analgesics, sleeping pills or any other substance that helps them to evade reality. That is why the experts recommend managing a change from a curative culture to a preventive one.

c. In response to the question: is there any evidence of successful changes towards a preventive culture in prisons, all the experts answered yes, there was. In the same prison, there are healthier habits amongst the inmates of the module for women convicted of terrorist activities. They are very disciplined in keeping their cells clean, take care of their personal hygiene, they do exercise such as yoga, which combines physical and mental health. They are also careful about their diet.

Another example is the Productive Prisons Programme (Programa cárceles productivas), implemented in the men's prisons, which has created workshops. The experts consider that it enabled physical diseases to be combated, there was a reduction in violent abuse or attacks amongst inmates, as a climate of mutual respect and cooperation was generated, while a significant decrease in mental illness. The programme also enabled inmates to feel that time in prison passed more quickly.

\section{Interview with the inmates}

a. They were asked: what do you think of prison conditions and if they protect your rights to health and a health environment? The inmates unanimously answered that the conditions are precarious, since they do not allow them to develop as persons and even less so when re-entering society after serving their sentence. They felt that they were treated like objects and not as human beings. Such a situation made them feel bad, which in turn affected their physical and mental health.

b. They were then asked: would you be willing to join a healthcare education programme? Most of the inmates answered that they would, because they understood that it make for a more bearable prison sentence.

c. The final question was: would you accept a stronger commitment to preventive medicine than to curative treatment? Most of the inmates agreed, with the proviso that such a situation would not mean the suspension of treatment or therapies for those who already had a physical or mental illness.

\section{CONCLUSIONS}

We agree with the answers of the experts and the inmates where they emphasise the importance of encouraging preventive medicine, and by doing so, providing a solid medical education in prisons. Curative medicine should be left to one side, without necessarily abandoning it. The female inmates generally spend most of their time in the dispensary asking for medication. This situation could become irreversible if craft workshops, recreational activities or sports are not promoted. Such activities would not only help to keep their minds occupied and help them to get fit, they would also help them to re-enter society more easily and make the sentence's role of social rehabilitation a reality. This state of affairs is commented on by Baca, Chacaltana, Roa, Zegarra and Bustamante ${ }^{5}$, who conclude that the situation of female inmates in Peru is a very complex one. Their level of education is very basic. Almost one fourth of the prison population has not studied or only went so far as to complete primary school. Changing this situation would also mean a change to the guarantees of their rights to health and an adequate environment. Concerns about infrastructure should not just be limited to investments in putting up more cement.

To conclude:

a. The prison infrastructure provides insufficient guarantees the right to health and an ade- 
quate environment for the female inmates of the Women's Annexe of Chorrillos Prison.

b. Current prison policies are limited to waiting for budgets to be allocated to build an infrastructure; or rather, more cold cement or to increase the amount of palliative drugs or sedatives, thereby removing the human dimension from the task of attempting to rehabilitate inmates into society.

c. This situation can be changed by a greater commitment to preventive medicine, without sidelining curative medicine, thus increasing inmates' educational levels through teaching and learning good habits that can help them to protect their physical and mental health.

d. More prison policies for inmates that promote craft workshops, sporting activities and recreational activities, would help to provide suitable and complete guarantees for their rights to health and an adequate environment.

\section{ACKNOWLEDGEMENTS}

We would like to thank the specialists and inmates who participated in this study. We would also like to express our gratitude to Ms. Marcely Berrocal Romero, for her unstinting support in processing the necessary authorisations for the prison.

\section{CORRESPONDENCE}

Carlos Vicente Navas

Universidad Nacional Federico Villarreal. Lima.

Perú

Dirección: Av. Nicolás de Piérola 351, Lima

E-mail: carlosvicentenavas@gmail.com

\section{REFERENCES}

1. Chaiña HG. Realidad penitenciaria y derechos humanos de los internos del Penal de Challapalca, Tacna 2011. [Tesis]. [Internet]. Escuela Profesional de Derecho. Facultad de Ciencias Jurídicas y Políticas. Universidad Nacional del Altiplano-PUNO; 2014. [fecha de acceso 1 Mar 2018]. Disponible en: http://repositorio.unap.edu.pe/bitstream/ handle/UNAP/1920/Chai\%C3\%B1a_Lopez_ Henry_German.pdf?sequence=1\&isAllowed=y

2 Tribunal Constitucional del Perú. Sentencia del expediente $\mathrm{N}^{\circ}$ 1429-2002-HC-TC. [Internet]. [fecha de acceso 2 Mar 2018]. Disponible en: http:// www.tc.gob.pe/jurisprudencia/2003/01429-2002HC.html

3 Corte Constitucional Colombiana. Sentencia T-760/08. [Internet]. [fecha de acceso $2 \mathrm{Mar}$ 2018]. Disponible en: https://www.minsalud.gov. $\mathrm{co} /$ sites/rid/Lists/BibliotecaDigital/RIDE/DE/ DIJ/Sentencia-T-760-08.pdf

4 Instituto Interamericano de Derechos Humanos. Manual de Buena Práctica Penitenciaria. Implementación de las reglas mínimas de Naciones Unidas para el tratamiento de los reclusos. Reforma Penal Internacional, 1997. [Internet]. [fecha de acceso 2 Mar 2018]. San José, CR; 1998. Disponible en: http://www.corteidh.or.cr/tablas/10616.pdf

5 Baca H, Chacaltana B, Roa Y, Zegarra T, Bustamante Z. Perfil de las reclusas en cárceles de Lima-Perú. [Internet]. [fecha de acceso 5 Mar 2018]. Rev Perú Obstet Enferm. 2015;11:10. Disponible en: http://www.aulavirtualusmp.pe/ojs/index. $\mathrm{php} / \mathrm{rpoe} /$ article/view/728/570 